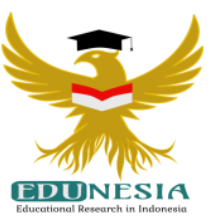

\title{
Authentic Assessment in Online Learning During The Covid-19 Pandemic
}

\author{
Masnurul Sholihah \\ Biology Education, SMPN 4 Danau Panggang, Indonesia. \\ Corresponding Email: masnurlsholihah@gmail.com, Phone Number: 0822 xxxx xxxx
}

\section{Article History:}

Received: Apr 30, 2021

Revised: Jun 08, 2021

Accepted: Jun 11, 2021

Online First: Jun 12, 2021

\section{Keywords:}

Authentic assessment, Covid-

19, Online learning.

Kata Kunci:

Covid-19, Pembelajaran online, Penilaian autentik.

\section{How to cite:}

Sholihah, M. (2021). Authentic Assessment in Online Learning During The Covid-19 Pandemic. Edunesia: Jurnal Ilmiah Pendidikan, 2 (2): 576-580.

This is an open access article under the $C C$-BY-NC-ND license

\begin{abstract}
This study aims to determine the ability of subject teachers in making an authentic instrument after studying the material about authentic assessment. The variables of this study include authentic instruments made by each subject teacher to be analyzed descriptively using a simple analytical rubric. The conclusion of this research is that after studying the material on authentic assessment, all subject teachers can make one or more authentic assessment instruments with the criteria for making the results of which the average is very good.
\end{abstract}

Abstrak: Penelitian ini bertujuan untuk mengetahui kemampuan guru mata pelajaran dalam membuat sebuah instrument autentik setelah mempelajari materi tentang penilaian autentik. Variabel penelitian ini meliputi instrumen autentik yang dibuat oleh setiap guru mata pelajaran untuk dianalisis secaradiskriftif menggunakan rubrik analitik sederhana. Kesimpulan dari penelitian ini adalah bahwa setelah mempelajari materi tentang penilaian autentik, semua guru mata pelajaran dapat membuat sebuah atau lebih instrumen penilaian autentik dengan kreteria hasil pembuatan yang rata-ratanya sangat baik. 


\section{A. Introduction}

Assessment or evaluation in the process of teaching and learning activities online or offline absolutely must be done to measure the success of a learning system run by a teacher. Assessment is a process result in a learning that begins with planning, implementation and evaluation or assessment (Farman et al, 2021).

In the Indonesian dictionary, the term assessment or evaluation has the meaning of assessment (Depdiknas, 2019). While evaluation in the world of education has a different meaning. But the word assessment is also part of the evaluation. According to Zainal Arifin, evaluation is broader in scope than assessment, while assessment is more focused on certain aspects that are part of that scope (Ani, 2013).

Some of the characteristics of authentic assessment include; (1) learner-centered, (2) is an integrated part of learning, (3) is contextual and depends on learning content, (4) reflects the complexity of learning, (5) uses various methods/procedures, (6) informs how learning or development program that should be carried out, and (7) qualitative (Sani, 2016).

Almost all teachers have difficulty in developing self-assessment tools. The ability of teachers in developing assessment tools is one of the descriptions of the quality of learning in schools (Zagoto, 2018), some teachers do not understand good and correct assessment tools in the final process of a learning activity, so it can be said that schools have not been able to develop assessment tools independently. The school hopes that the assessment carried out by a teacher is truly an authentic assessment, so that the learning process carried out by a teacher who is truly qualified or qualified in accordance with the demands of the government in educational assessment standards.

\section{B. Method}

The method of compiling this research is an offline and online literature study on Authentic Assessment material, then applied to all subject teachers to create an authentic instrument rubric according to their respective subjects.

The results of data collection will then be analyzed using a non-parametric statistical approach in a descriptive manner using purposive sampling in the form of an analytical rubric, with the following criteria; score, 9-12 = very good, 5-8 = quite good, 1-4 = not good (BELMAWA KPT Team, 2019)

\section{Result and Discussion}

The results of the research on authentic assessment are as summarized in the table below:

Table 1. Authentic Assessment by Subject Teachers

\begin{tabular}{ccc}
\hline Score total & Average & Criteria \\
\hline 140 & 9,33 & Very good \\
\hline
\end{tabular}




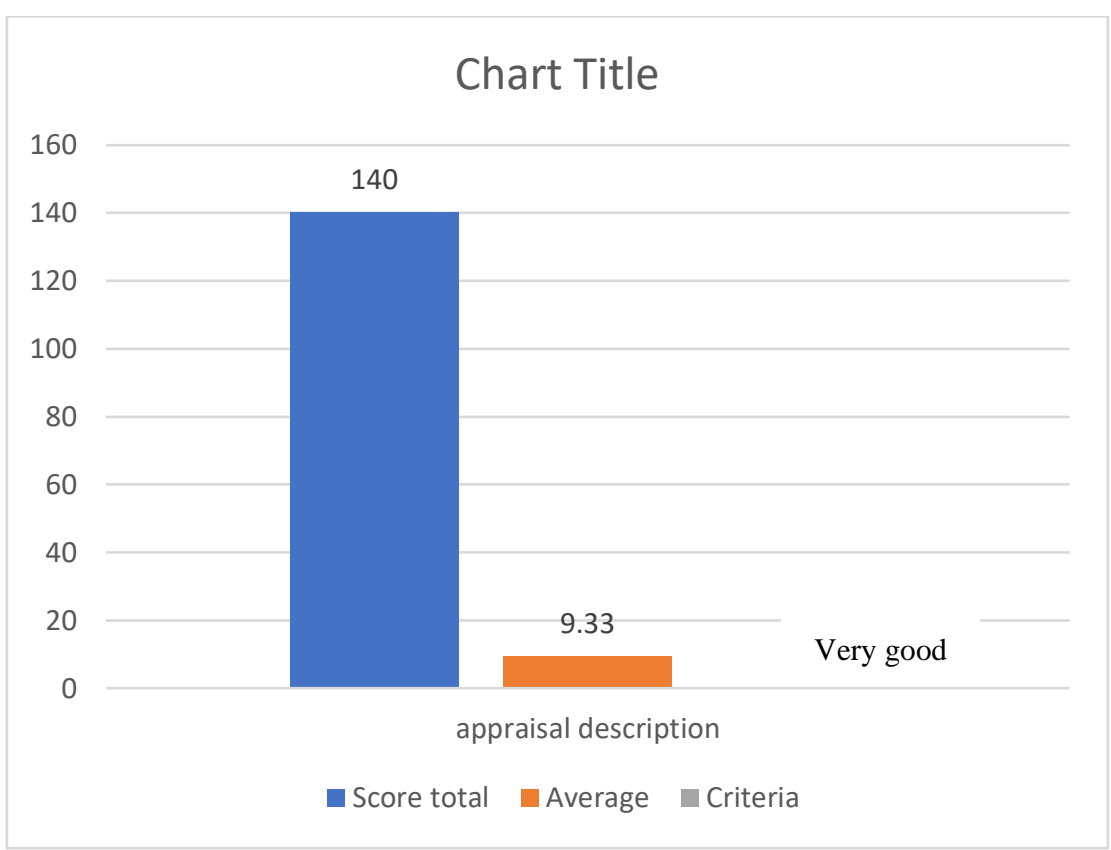

Figure 1. Appraisal description

The Assessment of Making Authentic Rubrics by Subject Teachers shows that after studying the material on authentic assessment all teachers can make one or more authentic assessment instruments with the criteria for making the average results very good.

The results showed that after studying the material on authentic assessment, all subject teachers were able to make one or more authentic assessment instruments with the criteria for making the average results very good. Thus all subject teachers can make one or more authentic assessment instruments with very good criteria that can produce one or more measuring tools for a meaningful measurement.

According to the Ministry of Education and Culture (2013), authentic assessment is a significantly meaningful measurement of student learning outcomes for the domains of attitudes, skills, and knowledge. So with the change in the paradigm of learning activities, what is in the learning process also changes, including assessment. At that time, the KTSP demanded the implementation of an assessment that referred to

Educational Assessment Standards. One of the assessment principles contained in the Regulation of the Minister of National Education of the Republic of Indonesia No. 20 of 2007 concerning Educational Assessment Standards is comprehensive and continuous. Thorough means that the assessment by the teacher covers all aspects of competence (cognitive aspects, psychomotor aspects and affective aspects) using various appropriate assessment techniques. Continuous means that the assessment is carried out to monitor the development of students' abilities (Wulandari, 2014).

From the facts that occur in the field, we assume that with the change in the KTSP curriculum to the 2013 curriculum, the assessment of the student learning process also changes continuously, so that it follows the procedures that are part of the 2013 curriculum and its revisions. Authentic assessment needs to be carried out for certain reasons.

There are several reasons for the need for an authentic assessment. Among them when conducting an assessment, many activities will be clearer if assessed directly, for example the ability to argue or argue, skills to use computers and skills to carry out 
experiments. Likewise, assessing students' attitudes or behavior towards something or when doing something.

Furthermore, for teachers or educators, it is necessary to know the extent of students' abilities during learning. So it takes an accurate assessment and can review all student activities. Assessment techniques that can be used to monitor actual (real) student progress during learning activities and not something made up are authentic assessment techniques (Arifin, 2010).

In another reference, according to the opinion that authentic assessment is the process of collecting various data that can provide an overview or information about the development of students' learning experiences. Thus it can be understood that authentic assessment is an assessment technique that is considered effective in collecting student data to determine student learning experiences during the learning process.

Meanwhile, according to Nurgiyantoro (2011), authentic assessment is concerned with assessing the process and results at the same time. Thus, all student appearances in a series of learning activities can be assessed objectively, as they are, and not solely based on the final result (product). After all, a lot of student performance is displayed during the learning activities so that the assessment must be carried out during and in line with the ongoing learning process activities.

The purpose of authentic assessment is planning the assessment of students in accordance with the competencies to be achieved and based on assessment principles, implementing student assessments in a professional, open, educative, effective, efficient manner, and in accordance with the socio-cultural context; and reporting the results of student assessments in an objective, accountable, and informative manner using certain assessments. According to Umami (2018), authentic assessment is a significantly meaningful measurement of student learning outcomes for the domains of attitudes, skills, and knowledge. The term assessment is a synonym for assessment, measurement, testing, or assessment. The term authentic is a synonym for genuine, real, valid, or reliable.

In short, authentic assessments are performance appraisals, portfolios, and project appraisals. Authentic assessment is sometimes called responsive assessment, a method which is very popular for assessing the process and learning outcomes of students who have special characteristics, ranging from those who experience certain disorders, have special talents and interests, to geniuses. Authentic assessment can also be applied in certain fields of science such as art or science in general, with the main orientation on the process or learning outcomes. Authentic assessment is often described as an assessment of student development, as it focuses on their developing ability to learn how to learn about a subject.

Authentic assessment must be able to describe what attitudes, skills, and knowledge students have or have not had, how they apply their knowledge, in what ways they have or have not been able to apply the learning gains, and so on.

\section{Conclusion}

The results showed that after studying the material on authentic assessment, all subject teachers were able to make one or more authentic assessment instruments with the criteria for making the average results very good.

Authentic assessment is the process of collecting various data that can provide an overview or information about the development of students' learning experiences. Thus it can be understood that authentic assessment is an assessment technique that is considered 
effective in collecting student data to determine student learning experiences during the online or offline learning process.

The types of authentic assessment are; Performance Appraisal, Appraisal Projects, Portfolio Assessments and Written Assessments

\section{References}

Ani, Y. (2013). Penilaian autentik dalam kurikulum 2013. In Seminar Nasional Implementasi Kurikulum (pp. 742-749).

Arifin, Z. (2011). Alternative Assessment Applied Approach Mengajar di Perguruan Tinggi, Jakarta: Pusat Antar Universitas untuk peningkatan dan pengembangan aktivitas instruksional, Ditjen Dikti Depdiknas, tt.

Depdiknas. (2019). Kamus Bahasa Indonesia, Jakarta: Pusat Bahasa.

Farman, F., Sarimuddin, S., Chairuddin, C., \& Hali, F. (2021). Pelatihan Penyusunan Soal Berbasis Luring dan Daring Menggunakan Wondershare Quiz Creator bagi Guru SMP. Community Empowerment.

Kemendikbud. (2013). Konsep Penilaian Autentik Pada Proses dan Hasil belajar, Badan Pengembangan Sumber Daya Manusia Pendidikan dan Kebudayaan dan Penjaminan Mutu Pendidikan.

Nurgiyantoro, B. (2011). Penilaian Otentik.Cakrawala Pendidikan, Th. XXVII, No.3.

Sani, R. A. (2016). Penilaian Autentik. Jakarta: Bumi Aksara.

Tim KPT BELMAWA. (2019). Panduan Latihan Pembuatan Rubrik. Ristekdikti: Jakarta.

Umami, I. (2018). Moderating influence of curriculum, pedagogy, and assessment practices on learning outcomes in Indonesian secondary education. Journal of Social Studies Education Research, 9(1), 60-75.

Wulandari.2014.Pengembangan Instrumen Penilaian Autentik Berbasis Kinerja Dalam Pembelajaran Fisika Model React Di Sma Kelas X Semester 2, FPMIPA Universitas Negeri Malang.

Zagoto, M. M. (2018). Pengembangan Perangkat Pembelajaran Matematika Berbasis Realistic Mathematic Educations Untuk Siswa Kelas V Sekolah Dasar. Jurnal Education And Development, 3(1), 53-53. 